\title{
Protein metabolism in chronic severe malnutrition (kwashiorkor)
}

\author{
Absorption and retention of nitrogen from a typical poor Mexican diet
By F. GÓMEZ, R. RAMOS-GALVÁN, J. CRAVIOTO, S. FRENK, CARMEN DE LA PEÑA, MARIA ELENA MORENO AND MARIA ELENA VILLA \\ Group for Research on Infantile Malnutrition, Hospital Infantil, Mexico City
}

(Received 28 May 1956-Revised 26 February 1957)

Variously known by such names as kwashiorkor (Africa), shibi gachaki (Japan), protein malnutrition (WHO), Mehlnährschaden (Germany), chronic severe malnutrition is one of the most prevalent pathological conditions suffered by children living in underdeveloped countries. Surveys carried out in different parts of the world have shown that the diets of such children are very similar, not only in their nutritional value, but also in the foodstuffs actually eaten. A typical dietary history is as follows: (I) prolonged breast feeding on an inadequate lactation; (2) improper weaning with cereals (especially corn (maize) meal cooked by the action of quicklime), beans and peppers; (3) lack of milk, meat, fish and eggs after weaning. That is to say the diet after weaning is low in calories, fats and proteins, high in carbohydrates, and contains insufficient amounts of vitamins and minerals. The intake of most of the children meets no more than $50 \%$ of the caloric, and from 20 to $60 \%$ of the protein, requirement. Fats, usually vegetable fats, are consumed in amounts one-third below normal (Lozoya-Dávila, I946; Ramos-Galván, I948; Meneghello, I949; Housden, 1950; Brock \& Autret, 1952; Gómez, Ramos-Galván \& Cravioto, I952; Davies, 1952; Trowell, Davies \& Dean, I954).

The disease usually occurs before school age(Gillman \& Gillman, I 95 ; MacPherson, I953; Gómez, Ramos-Galván, Cravioto \& Frenk, I954 $a$; Netrasiri \& Netrasiri, 1955; Gopalan, 1956), with $80 \%$ of the affected subjects between I and 4 years of age. Very few metabolic studies in this age group have so far been published.

We are not aware of any studies of malnourished children of pre-school age while on a typical diet of maize meal and beans. This paper deals with nitrogen absorption and retention in severely malnourished children aged from $x$ to 5 years, maintained on such a diet.

A child is considered to have protein malnutrition if the following signs are found (Gómez et al. 1954a; Trowell et al. 1954): (1) Body-weight below the standard weight for age. (2) Body length below the standard height for age. (3) Delay in bone growth as judged by radiological age. (4) Discoloration and changes in the hair. (5) Increase of extracellular fluid with or without clinical oedema. (6) Skin lesions of variable intensity, which may be classified into one of three main groups: $(a)$ extensive 
hyperchromic dyskeratotic lesions which are symmetrical and localized to zones exposed to sunlight; $(b)$ macular lesions, frequently coalescent, involving the whole surface of the body, especially those zones not exposed to light; $(c)$ lesions that seem to begin with a 'marbled' appearance and later become reticulated. (7) Changes in the serum proteins with low serum albumin and high $\gamma$-globulin levels. (8) Mild normocytic normochromic anaemia.

\section{EXPERIMENTAL}

Subjects. Eight male children, all having the signs described, were placed on metabolic beds. Ages, body-weights and heights are shown in Table I, together with standard weights for Mexican children of the same ages (Gómez et al. 1954b).

\section{Table r. Ages, heights and weights of malnourished children on admission to the metabolic unit}

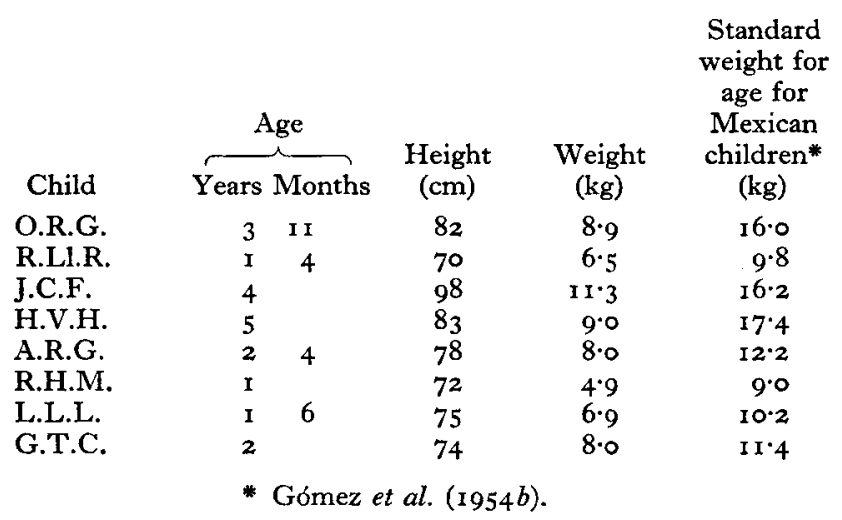

The average weight of the children was about $40 \%$ of the standard weight for their age, which is typical of severe malnutrition. In spite of this tremendous weight deficit, if such a child has a good appetite, and is free from infections and acute electrolyte disturbances, his chances of survival are quite good (Gómez, Ramos-Galván, Cravioto, Frenk \& Chávez, 1956). All the children in the group studied conformed to these conditions. Obviously, uncomplicated cases must be chosen for this type of study.

Diet. Children admitted to the hospital in this clinical state have a slow rate of recovery if given a diet of maize and beans similar to that eaten at home. Since protein foodstuffs of animal origin are not normally consumed by these children, it is of great importance to try to find a practical diet, based on foods familiar to them, that will have curative value if given in adequate amounts.

The time spent by the children in the metabolic unit varied from Io to 15 days. During this period the recovery was necessarily slow. When the investigation was completed the children were given a full, balanced diet and recovery took place at a normal rate (Gómez et al. 1952). All recovered and were discharged after about 50 days.

Two of the children (O.R.G. and J.C.F.) had received for a 4-day period before 
this study a supplement of $400 \mathrm{mg} /$ day of L-lysine. It is considered unlikely that this supplement had any influence on the subsequent balance studies.

Maize (Zea mais) cooked in quicklime and beans (Phaseolus vulgaris L.) cooked in water with the addition of $\mathrm{I}$ oz. olive oil and 4 or $5 \mathrm{~g}$ salt to every $200 \mathrm{~g}$ beans made up the initial diet. Drinking water was offered freely.

Duplicate nitrogen determinations were done on samples of the diet at each preparation.

Balance studies. The metabolic periods lasted 4 days. Urine and faeces were collected separately. The stools were marked with carmine at the beginning and at the end of each period.

\section{RESULTS}

The metabolic findings are shown in Table 2.

Table 2. Mean daily calorie intake and intake, excretion and balance of nitrogen by severely malnourished children on a diet of maize and beans

\begin{tabular}{|c|c|c|c|c|c|c|c|c|}
\hline \multirow[b]{3}{*}{ Child } & \multirow[b]{3}{*}{$\begin{array}{c}\text { Calorie } \\
\text { intake } \\
\text { (Cal.) }\end{array}$} & \multicolumn{7}{|c|}{ Nitrogen } \\
\hline & & \multirow[b]{2}{*}{$\begin{array}{c}\text { Intake } \\
\text { (g) }\end{array}$} & \multicolumn{3}{|c|}{ Excretion } & \multirow[b]{2}{*}{$\begin{array}{c}\text { Balance } \\
\text { (g) }\end{array}$} & \multirow{2}{*}{$\begin{array}{c}\text { Retained } \\
\text { (mg/kg } \\
\text { body- } \\
\text { weight) }\end{array}$} & \multirow{2}{*}{$\begin{array}{l}\text { Intake } \\
\text { (mg/kg } \\
\text { body- } \\
\text { weight) }\end{array}$} \\
\hline & & & $\begin{array}{l}\text { Urinary } \\
\text { (g) }\end{array}$ & $\begin{array}{c}\text { Faecal } \\
\text { (g) }\end{array}$ & $\begin{array}{c}\text { Total } \\
\text { (g) }\end{array}$ & & & \\
\hline O.R.G. & 996 & $5 \cdot 34$ & 0.45 & 5.04 & $5 \cdot 49$ & -0.15 & -17 & 600 \\
\hline R.LI.R. & 500 & $3 \cdot 26$ & 0.46 & $1 \cdot 92$ & $2 \cdot 38$ & +0.88 & +135 & 504 \\
\hline J.C.F. & $\times 162$ & $8 \cdot 50$ & 0.93 & $4 \cdot 48$ & $5 \cdot 4 \mathrm{I}$ & +3.09 & +274 & 752 \\
\hline H.V.H. & 332 & $2 \cdot 81$ & 0.77 & 1.68 & $2 \cdot 45$ & +0.36 & +40 & 313 \\
\hline A.R.G. & 336 & $2 \cdot 15$ & 0.87 & $I \cdot 85$ & $2 \cdot 72$ & -0.57 & -72 & 269 \\
\hline R.H.M. & 340 & I. 54 & 0.84 & $I \cdot 24$ & $2 \cdot 08$ & -0.54 & - III & 316 \\
\hline L.L.L. & 337 & $2 \cdot 29$ & 0.62 & 0.97 & I.59 & +0.70 & +102 & 333 \\
\hline G.T.C. & 429 & $2 \cdot 00$ & 0.77 & $I \cdot 91$ & 2.68 & -0.68 & -85 & $25^{2}$ \\
\hline
\end{tabular}

With a good-quality protein, nitrogen retention closely reflects intake. Figs. I and 2 show the correlation existing between the intake, absorption and retention per $\mathrm{kg}$ body-weight in comparison with previous values obtained for a similar group of

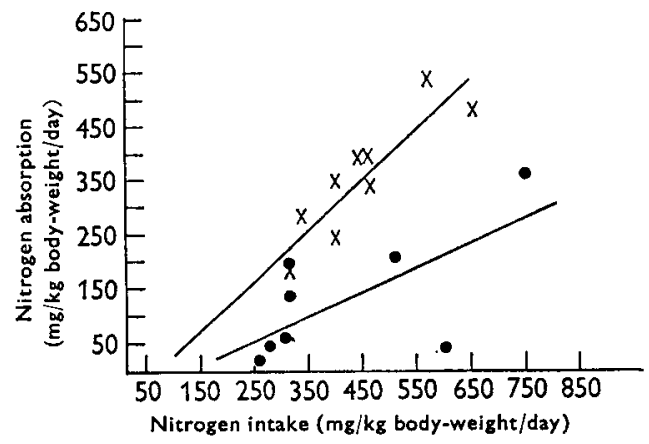

Fig. I. Correlation between nitrogen intake and nitrogen absorption in children with chronic severe malnutrition. $x$, milk diet (Gómez, Ramos-Galván, Cravioto, Frenk, De la Peña \& Moreno, I956); 0 , diet of maize meal and beans (this study). 
malnourished children fed on cow's milk (Gómez, Ramos-Galván, Cravioto, Frenk, De la Peña \& Moreno, 1956).

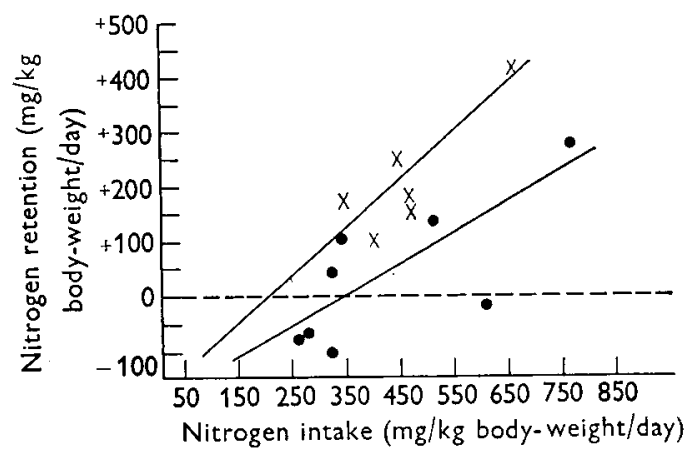

Fig. 2. Correlation between nitrogen intake and nitrogen retention in children with chronic severe malnutrition. $x$, milk diet (Gómez, Ramos-Galván, Cravioto, Frenk, De la Peña \& Moreno, 1956); $\bullet$, diet of maize meal and beans (this study).

Because the children in the present study varied in age and weight, although the disease was of about the same severity in all, it was thought necessary to calculate absorption and retention as percentages of intake (Table 3 ).

The correlation coefficients between intake and balance and between intake and absorption were, respectively, +0.72 and +0.64 .

Table 3. Nitrogen absorbed and nitrogen retained by severely malnourished children on a diet of maize and beans, expressed as a percentage of nitrogen intake

\begin{tabular}{|c|c|c|c|c|}
\hline \multirow[b]{2}{*}{ Child } & \multirow{2}{*}{$\begin{array}{l}\text { Nitrogen } \\
\text { intake } \\
\text { (g/day) }\end{array}$} & \multicolumn{2}{|c|}{ Nitrogen absorbed } & \multirow{2}{*}{$\begin{array}{l}\text { Nitrogen } \\
\text { retained } \\
\text { (percentage } \\
\text { of intake) }\end{array}$} \\
\hline & & $\mathrm{g} /$ day & $\begin{array}{c}\text { Percentage } \\
\text { of intake }\end{array}$ & \\
\hline O.R.G. & $5 \cdot 34$ & 0.30 & $5 \cdot 6$ & $-2 \cdot 8$ \\
\hline R.Ll.R. & $3 \cdot 26$ & $\mathrm{I} \cdot 34$ & $4 I \cdot I$ & $26 \cdot 9$ \\
\hline J.C.F. & $8 \cdot 50$ & $4^{\circ} 02$ & $47 \cdot 3$ & $36 \cdot 4$ \\
\hline H.V.H. & $2 \cdot 8 \mathrm{I}$ & $I \cdot 13$ & $40 \cdot 2$ & $12 \cdot 8$ \\
\hline A.R.G. & $2 \cdot 15$ & 0.30 & $1_{3} \cdot 8$ & $-26 \cdot 7$ \\
\hline R.H.M. & $x \cdot 53$ & 0.29 & $19 \cdot 2$ & $-35 \cdot 3$ \\
\hline L.L.L. & $2 \cdot 29$ & $I \cdot 32$ & $57 \cdot 6$ & $30 \cdot 6$ \\
\hline G.T.C. & $2 \cdot 00$ & 0.10 & $4 \cdot 8$ & $-33 \cdot 6$ \\
\hline
\end{tabular}

DISCUSSION

Some of our findings seem to warrant discussion. In the first place, it is apparent from Table 3 that the nitrogen absorption varied considerably from one child to another, the figures ranging from 0.10 to $4.02 \mathrm{~g} /$ period. The absorption calculated as a percentage of intake was also extremely variable, ranging from $4^{\cdot 8}$ to $57^{\cdot 6}$. The relatively low correlation coefficient, +0.64 , shows that absorption on the diet of maize and beans was little influenced by the nitrogen intake. By contrast, on a plain milk diet the correlation coefficient between intake and absorption was $+0.97 \pm 0.0 \mathrm{I}$ (Gómez, Ramos-Galván, Cravioto, Frenk, De la Peña \& Moreno, r956). 
In the same way, nitrogen balance was either positive or negative. Some of the variability in the present study may have been due to experimental error, but the results seem to show that the relationship between nitrogen intake and retention on a diet of maize and beans is less close than on a milk diet. The caloric intake was low in comparison to the requirements of normal children of this age or even of this weight. Nevertheless, since similar amounts of calories and nitrogen if provided by cow's milk induce a positive balance and recovery from malnutrition, the observed differences cannot be explained on the basis of caloric intake, especially since negative and positive balances were observed at similar caloric intakes.

The fact that some children showed good nitrogen retention may help to explain why all children living on deficient diets do not develop the typical clinical signs of severe malnutrition and why some of those who do begin to get better solely on this diet.

The degree of variation between children means that the use of even a large independent control group would not enable precise comparisons to be made; it is therefore best to use each child as its own 'control'.

\section{SUMMARY}

I. Nitrogen-balance experiments were made on eight children aged from $I$ to 5 years affected with chronic severe malnutrition. During the experiment they were kept on a diet of corn (maize) meal and beans.

2. Both nitrogen absorption and nitrogen retention were extremely variable from one child to another. Four children were in positive nitrogen balance and four in negative. No correlation could be found between the caloric intake and the nature of the balance.

3. The fact that some children retained nitrogen from a diet as poor as this may help to explain why some develop severe malnutrition and others remain reasonably healthy even when all have almost the same dietary habits.

This work was supported by a grant from Mead Johnson and Co., Evansville, Ind., U.S.A.

\section{REFERENCES}

Brock, J. F. \& Autret, M. (1952). W.H.O. Monogr. Ser.no. 8.

Davies, J. N. P. (1952). Annu. Rev. Med. 3, 99.

Gillman, J. \& Gillman, T. (1951). Perspectives in Human Malnutrition. New York: Grune and Stratton. Gómez, F., Ramos-Galván, R. \& Cravioto, J. (1952). Pediatrics, Springfield, 1o, 5 I3.

Gómez, F., Ramos-Galván, R., Cravioto, J. \& Frenk, S. (1954a). Acta paediat., Uppsala, 43, Suppl. Ioo, p. 336 .

Gómez, F., Ramos-Galván, R., Cravioto, J. \& Frenk, S. (1954b). Advanc. Pediat. 7, I3 I.

Gómez, F., Ramos-Galván, R., Cravioto, J., Frenk, S. \& Chávez, R. (1956). F. trop. Pediat. $2,77$.

Gómez, F., Ramos-Galván, R., Cravioto, J., Frenk, S., De la Peña, C. \& Moreno, M. E. (I956). Rev. Invest. clin., Méx., 9, $4 \mathbf{I}$.

Gopalan, C. (1956). Ұ. trop. Pediat. x, 206.

Housden, L. (1950). Brit. med. $\mathcal{F}$. ii, 456.

Lozoya-Dávila, J. C. (1946). Contribución al estudio de la alimentación en la segunda y tercera infancia. Thesis, Escuela Médico Militar, México.

MacPherson, A. (1953). Lancet, 264, I I 54.

Meneghello, J. (1949). La Desnutrición en el Lactante Mayor. Santiago de Chile: Central de Publicaciones.

Netrasiri, A. \& Netrasiri, C. (1955). F. trop. Pediat. I, 148.

Ramos-Galván, R. (1948). Bol. med. Hosp. infant., Méx., 5, $45 \mathrm{I}$.

Trowell, H.C., Davies, J. N. P. \& Dean, R.F.A. (1954). Kwashiorkor. London: E. Arnold Publishers Ltd. 